\title{
Thermococcus gorgonarius sp. nov. and Thermococcus pacificus sp. nov.: heterotrophic extremely thermophilic archaea from New Zealand submarine hot vents
}

\author{
M. L. Miroshnichenko, ${ }^{1}$ G. M. Gongadze, ${ }^{2}$ F. A. Rainey, ${ }^{3} \dagger$ \\ A. S. Kostyukova, ${ }^{4}$ A. M. Lysenko, ${ }^{1}$ N. A. Chernyh ${ }^{1}$ \\ and E. A. Bonch-Osmolovskaya ${ }^{1}$
}

Author for correspondence: E. A. Bonch-Osmolovskaya. e-mail: lbo@imbran.msk.su

1 Institute of Microbiology,
Russian Academy of
Sciences, Moscow, Russia
2 Institute of Biophysics,
Russian Academy of
Sciences, Moscow, Russia
3 German Collection of
Microorganisms and Cell
Cultures, Braunschweig,
Germany
4 Institute of Protein
Research, Russian Academy
of Sciences, Pushchino,
Moscow Region, Russia

\begin{abstract}
Two extremely thermophilic archaea, designated W-12 and P-4, were isolated from a geothermal vent in the tidal zone of Whale Island, New Zealand, and from geothermally heated bottom deposits of the Bay of Plenty, New Zealand, respectively. Cells of isolate $W-12$ are irregular cocci, 0.3-1.2 $\mu \mathrm{m}$ in diameter, motile with polar flagella. The cell envelope consists of one layer of subunits with a major protein of $M_{r} \mathbf{7 5 0 0 0}$. Cells produce protrusions of different kinds: prostheca-like, chains of bubbles, or network of fimbriae. Cells of isolate P-4 are regular cocci, 0.7-1.0 $\mu \mathrm{m}$ in diameter, motile with polar flagella. The cell envelope consists of two layers of subunits; its major protein has an $M_{r}$ of 56000 . Both organisms are obligate anaerobes, fermenting peptides in the case of strain W-12, or peptides and starch in the case of P-4. Elemental sulfur is required for growth and is reduced to hydrogen sulfide. The optimal growth temperature of the new isolates is in the range $80-88{ }^{\circ} \mathrm{C}$. The optimal growth pH is 6.5-7.2. The G+C content of the DNA of strain W-12 is $50.6 \mathrm{~mol} \%$, and of strain P-4 is $53.3 \mathrm{~mol} \%$. Based on physiological characteristics, 165 rDNA sequence comparison and DNA base composition, the new isolates were considered to be members of the genus Thermococcus. The low level of DNA-DNA hybridization with the type strains of other Thermococcus species confirms the novel species status of the new isolates. The new isolates are described as Thermococcus gorgonarius sp. nov., with type strain W-12 (= DSM 10395'), and Thermococcus pacificus sp. nov., with type strain P-4 (= DSM 10394').
\end{abstract}

Keywords: Thermococcus gorgonarius sp. nov., Thermococcus pacificus sp. nov., thermophiles, archaea

\section{INTRODUCTION}

During the last decade, a number of extremely thermophilic archaea, among which sulfur-dependent organotrophs are the most abundant, have been isolated from marine sources $(16,25)$. With the exception of Pyrodictium abyssi (20), which has flat cells with a complicated network of filaments, all the extremely thermo-

†Present address: Department of Biological Sciences, Louisiana State University, Baton Rouge, LA 70803, USA.

The EMBL accession numbers for the partial sequences described in this paper are Y16226 and Y16227. philic anaerobic organotrophs are coccoid in shape, often with a bundle of flagella. Extremely thermophilic organotrophic cocci belong to the genera Thermococcus $(7,9-12,16-18,27)$, Pyrococcus $(3,4)$, Staphylothermus (5) and Hyperthermus (28). Although only remotely related phylogenetically, they are quite similar in physiological and morphological characteristics. These organisms grow anaerobically on peptides or polysaccharides and sugars. It has been shown for representatives of several genera that elemental sulfur serves as a sink for electrons released in the course of fermentation but not as an electron acceptor (1). Here we describe two new representatives of the genus Thermococcus isolated from geothermally heated 

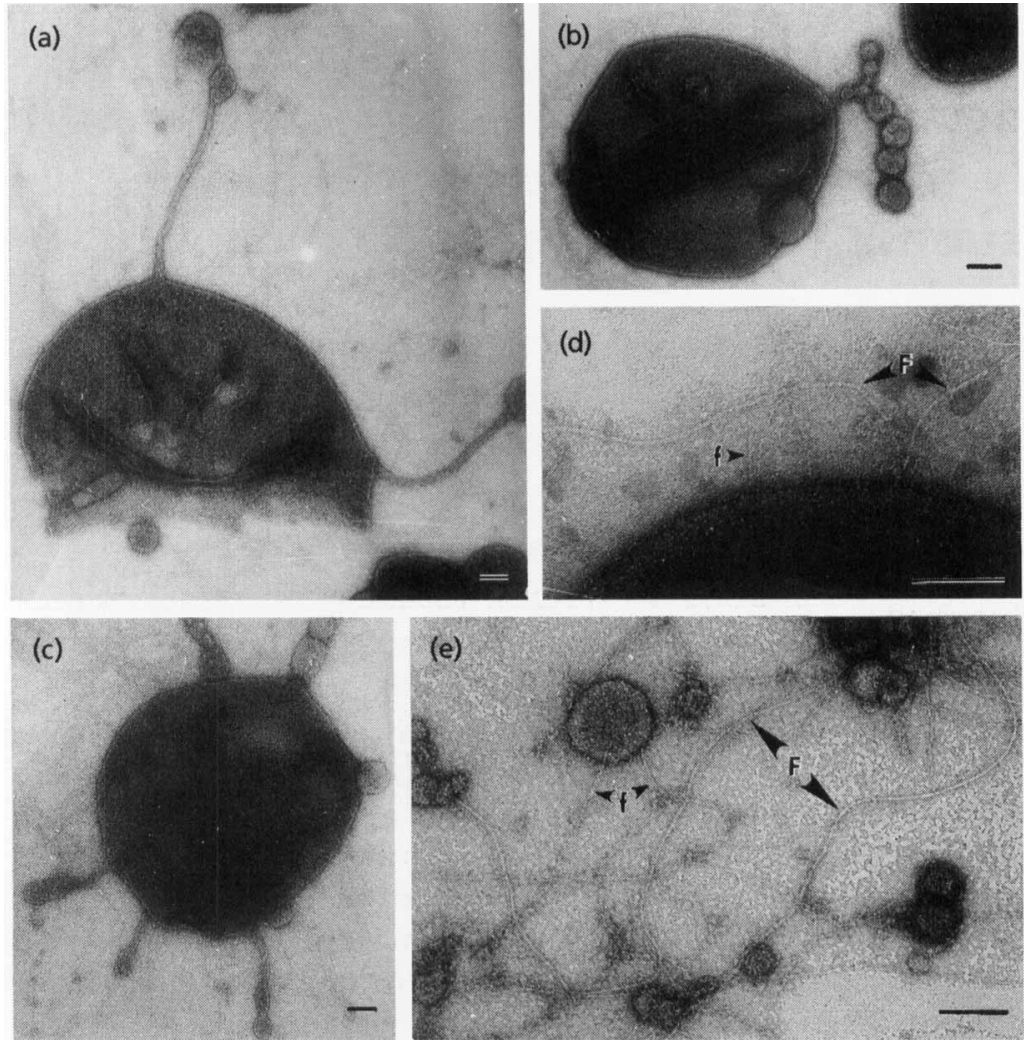

(e)

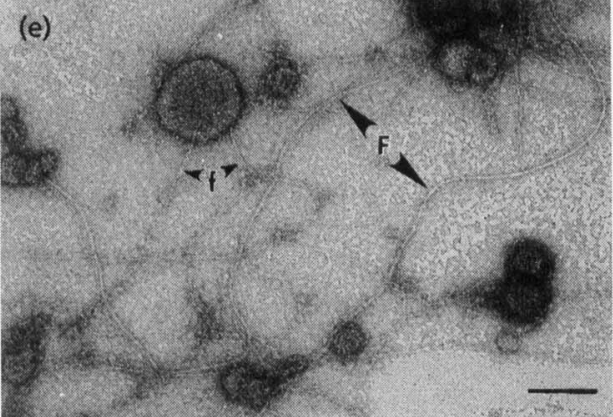

Fig. 1. Electron micrographs of negatively stained preparations of isolate W-12 cells, showing chains of blebs and prostheca-like appendages $(a-c)$, flagella and fimbriae (d-e). F, Flagella, f, fimbriae. Bars, $100 \mathrm{~nm}$. deposits of shallow-water submarine vents in New Zealand.

\section{METHODS}

Sources and sampling. Samples from submarine hot vents in New Zealand were obtained during the 18th scientific cruise of the research vessel 'Academic Nesmeyanov', which took place in 1990. Shallow-water hot vents of the Bay of Plenty and Whale Island were investigated. On Whale Island, there is an area of geothermal activity in the tidal zone of the northern coast. When the tide was low, samples of the hot sand with a temperature of $85^{\circ} \mathrm{C}$ were collected in glass vessels, hermetically closed and transported to the ship. Samples of geothermally heated mud from the bottom of the Bay of Plenty were obtained from $40 \mathrm{~m}$ depth with a sampling device. The temperature of mud when brought to the surface was $85^{\circ} \mathrm{C}$.

Enrichment and isolation. For enrichment cultures of extreme thermophiles, anaerobically prepared marine medium (17), supplemented with peptone $(0.5 \%, \mathrm{w} / \mathrm{v})$ and elemental sulfur $(1 \%, \mathrm{w} / \mathrm{v})$ was used. The $\mathrm{pH}$ was adjusted to 6.5 with $5 \mathrm{M} \mathrm{H}_{2} \mathrm{SO}_{4}$ and the medium was dispensed into Hungate tubes $(15 \mathrm{ml})$; the head space $(5 \mathrm{ml})$ was filled with a $\mathrm{N}_{2} / \mathrm{CO}_{2}$ gas mixture. Inoculated tubes were incubated at $88^{\circ} \mathrm{C}$. Pure cultures were obtained by isolating colonies in roll-tubes, prepared with the same medium solidified with $0 \cdot 8-1 \%$ (w/v) Gelrite (Gellangum, Kelco). In this case sulfur was substituted by polysulfide (26).

Reference strains. The type strain of Thermococcus celer DSM $2476^{\mathrm{T}}$ was obtained from K. O. Stetter (University of Regensburg, Germany). The type strain of Thermococcus stetteri DSM $5262^{\mathrm{T}}$ was maintained in the culture collection of the Institute of Microbiology, Russian Academy of Sciences, Moscow, Russia. The other reference strains were obtained from the German Collection of Microorganisms and Cell Cultures, Braunschweig, Germany.

Microscopy. Observations of microbial growth in enrichments and pure cultures were made using a light microscope AU-12, equipped with phase contrast. Freeze-etching, negative staining and the preparation of thin sections for electron microscopy were as described previously (8).

Studies of cell wall proteins. Electrophoresis and staining methods have been described previously (8).

Physiological studies. Growth substrates, when tested, were added to the same mineral medium as used for enrichments, in concentrations of $0.5 \%(\mathrm{w} / \mathrm{v}) . \mathrm{H}_{2} / \mathrm{CO}_{2}(80: 20)$ was added to the headspace of culture tubes. Possible electron acceptors other than elemental sulfur were added to sulfur-free medium with peptone in concentrations of $0.2 \%(\mathrm{w} / \mathrm{v})$. These included thiosulfate, sulfate, sulfite, fumarate and nitrate as their sodium salts. For growth $\mathrm{pH}$ characteristics, the $\mathrm{pH}$ of the medium was adjusted at ambient temperature before inoculation by the addition of $5 \mathrm{M} \mathrm{H}_{2} \mathrm{SO}_{4}$ or $5 \mathrm{M}$ $\mathrm{NaOH}$. Cell growth was monitored by direct cell counting using a light microscope with phase-contrast optics. Hydrogen sulfide was determined by the colorimetric method (24). Products of metabolism were determined using a gas chromatograph Chrom-5 with a flame-ionization detector on a column packed with Chromosorb 10 (Sigma) at $170^{\circ} \mathrm{C}$, using argon as a carrier gas at a flow rate of $40 \mathrm{ml} \mathrm{min}^{-1}$.

DNA characteristics. DNA was isolated according to the methods of Marmur (15), with additional pronase treatment $\left(50 \mathrm{mg} \mathrm{ml}^{-1}\right.$, for $2 \mathrm{~h}$ at $37^{\circ} \mathrm{C}$ ) before 2-propanol fractionation. The $\mathrm{mol} \% \mathrm{G}+\mathrm{C}$ content of the DNA was determined by melting point analysis (19). To determine DNA homology 
with type strains of other species, DNA was immobilized on nitrocellulose filters (10 $\mathrm{mg}$ per filter) and reassociated under optimal conditions (6). Labelled DNA was obtained using the nick-translation reaction and incorporation of $\left[{ }^{3} \mathrm{H}\right]$ cytidine (14). Partial 16S rDNA sequences were determined as described previously $(2,21)$. The partial $16 \mathrm{~S}$ rDNA sequences were manually aligned using the ae 2 editor (13) and sequence similarity values calculated by pairwise sequence comparison (13). The sequences were compared against the 16S rRNA/DNA sequences for Thermococcus strains available from the public databases.

\section{RESULTS}

\section{Enrichment and isolation}

Samples of sand from the shore of Whale Island and bottom sediments from a $40 \mathrm{~m}$ depth in the Bay of Plenty were inoculated into anaerobic sulfur- and peptone-containing medium and incubated at $88^{\circ} \mathrm{C}$. Bacterial growth was observed after a $6-20 \mathrm{~h}$ incubation. When transferred to solidified medium, colonies appeared after $8-10 \mathrm{~h}$ incubation at $88^{\circ} \mathrm{C}$. They were regular, round, semi-transparent, and about $0.5 \mathrm{~mm}$ in diameter. Colonies were transferred into liquid medium. The isolate from the shore of Whale Island was designated strain $\mathrm{W}-12$, the isolate from deposits of the Bay of Plenty designated strain P-4.

\section{Morphology and fine structure}

Cells of isolate W-12 were of variable size. Most cells were $0.4-0.6 \mu \mathrm{m}$ in diameter, but sometimes larger cells with diameter up to $1.2 \mu \mathrm{m}$ were also present. Different kinds of protrusions could be observed (Fig. 1a-e). About $50 \%$ of cells contained long prostheca-like protrusions (Fig. 1a, c; Fig. 2c, d). The protrusions had an interior channel and terminal enlargements. Some cells had extracellular structures (Fig. 1b, c) consisting of several chains of bubbles apparently derived from cell envelope material. Polar flagella were also present (Fig. 1d). Flagella were very thin, $5-5.5 \mathrm{~nm}$ in width. Besides the flagella, a thin network of fimbriae 3-3.5 $\mathrm{nm}$ in width was also observed (Fig. 1e). The cell envelope of isolate W-12 consisted of one layer of subunits $15 \mathrm{~nm}$ in width attached to a plasma membrane and regularly packed (Fig. 2a, b). The major protein of the cell envelope had an $M_{\mathrm{r}}$ of 75000 . Alcian blue staining for glycoproteins was positive (Fig. 4).

Cells of isolate P-4 were of more regular coccoid shape (Fig. 3a); no protrusions of any kind were ever observed. Polar flagella were present (Fig. 3b). The cell wall of P-4 consisted of two layers with a total width of $30 \mathrm{~nm}$ (Fig. 3c, d). The outer layer looked as if it had been partly destroyed, probably being less stable than the inner one.

One of the most intense bands in the cell protein profile of isolate P-4 represented a protein with $M_{\mathrm{r}} 56000$ (data not shown). A band of the same $M_{\mathrm{r}}$ was the major one in the set of proteins from isolated cell envelopes (Fig. 4, lane 4), while the amounts of the other proteins of this set varied in different preparations. Based on these data it was presumed that the protein of $M_{\mathrm{r}} 56000$ is a regularly structured S-layer protein (RS protein).

\section{Physiological characteristics}

Strain W-12 was able to grow in the temperature range $68-95^{\circ} \mathrm{C}$ with the optimum at $80-88^{\circ} \mathrm{C}$. Strain P-4 grew in the temperature range $70-95^{\circ} \mathrm{C}$ with the optimum at $80-88^{\circ} \mathrm{C}$. The $\mathrm{pH}$ range of growth was $5.8-8.5$ for strain $\mathrm{W}-12$ with the optimum at $6 \cdot 5-7 \cdot 2$ and $6.0-8.0$ for strain P-4 with the optimum at 6.5 . Both strains required $\mathrm{NaCl}$ for growth: $1 \cdot 0-5 \cdot 0 \%$ $(\mathrm{w} / \mathrm{v})$ for strain $\mathrm{W}-12$ and $1 \cdot 0-6.0 \%(\mathrm{w} / \mathrm{v})$ for strain $\mathrm{P}-4$. Optimal growth of both strains occurred at $2-3.5 \%(\mathrm{w} / \mathrm{v}) \mathrm{NaCl}$. The growth substrates utilized in the case of strain W-12 were peptone and yeast extract; only weak growth was observed on pyruvate. For strain P-4, peptone, yeast extract, and starch served as substrates for growth. No growth of either isolate occurred in media supplemented with Casamino acids, glucose, maltose, lactate, acetate, propionate, methanol, ethanol, or under $\mathrm{H}_{2} / \mathrm{CO}_{2}$ atmosphere. Strain W-12 was also unable to grow on starch, and strain P-4 did not utilize pyruvate. The end products of growth of both strains on medium with peptone and elemental sulfur were $\mathrm{H}_{2} \mathrm{~S}, \mathrm{CO}_{2}$, acetate, propionate, isobutyrate and isovalerate. Neither isolate grew in the absence of elemental sulfur. Elemental sulfur could not be substituted by thiosulfate, sulfite, sulfate, cystine, fumarate or nitrate.

\section{DNA characteristics}

The $\mathrm{G}+\mathrm{C}$ contents of the DNA of isolates $\mathrm{W}-12$ and P-4 were $50.6 \mathrm{~mol} \%$ and $53.3 \mathrm{~mol} \%$ respectively. Results of DNA-DNA reassociation experiments are presented in Table 1. Low levels of DNA-DNA reassociation were found between some of the previously described Thermococcus species and strains P-4 and W-12.

Partial 16S rDNA sequences comprising 1142 and 1143 nucleotides were determined for strains W-12 and P-4 respectively. Since the $16 \mathrm{~S}$ rDNA sequence of Thermococcus peptonophilus (accession no. D37982) comprises only 924 nucleotides, the region of sequence available for comparison between all strains was limited to 700 nucleotides in the regions $101-319$ and 556-976 (Escherichia coli positions). Strains W-12 and P-2 showed $98.6 \% 16$ S rDNA similarity to each other. High 16S rDNA similarity values ranging between $97 \cdot 7$ and $99 \cdot 4 \%$ were found between strains W-12, P-4 and the Thermococcus species for which 16S rDNA sequences are available. Strain W-12 showed highest partial $16 \mathrm{~S}$ rDNA sequence similarity $(99.4 \%)$ to $T$. celer and Thermococcus profundus. Strain P-4 showed highest $16 \mathrm{~S}$ rDNA sequence similarity $(99 \cdot 2 \%)$ to $T$. stetteri. The lowest 16S rDNA sequence similarity values (both $97.8 \%$ ) found between the isolates and Thermococcus species are to Thermococcus fumicolans. 

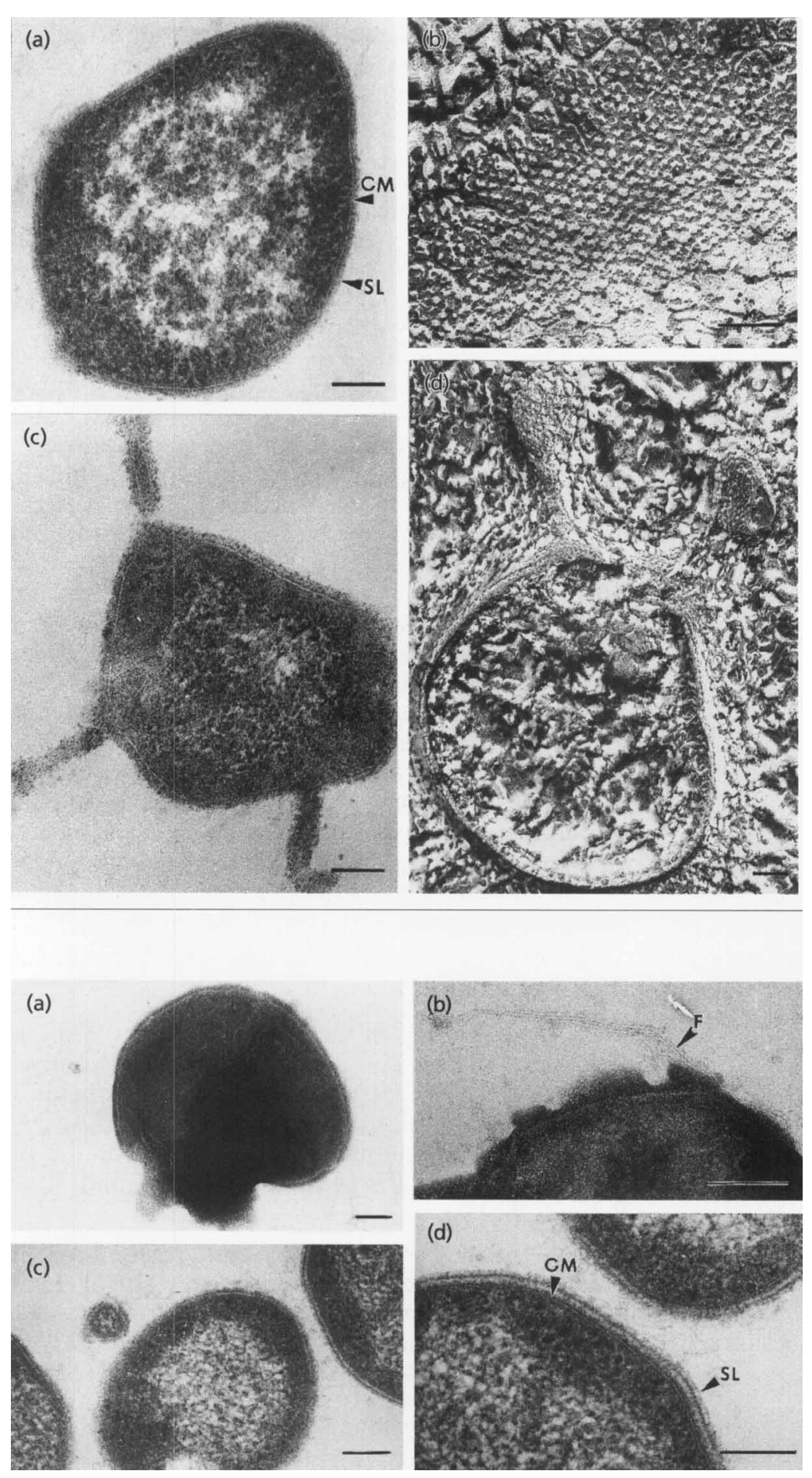

Fig. 2. Electron micrographs of thin sections of isolate W-12 cells $(a, c)$ and freeze-etch replica of cells (b, d). CM, Cytoplasmic membrane; SL, surface layer. Bars, $100 \mathrm{~nm}$.
Fig. 3. Electron micrographs of isolate $P-4$ cells: negatively stained preparations $(a, b)$ and thin sections (c, d). F, Flagella; CM, cytoplasmic membrane; SL, surface layer. Bars, $100 \mathrm{~nm}$.
16S rDNA sequence similarities in the range 96.1$97.4 \%$ were found between strains W-12, P-4 and the Pyrococcus species.

\section{DISCUSSION}

The new isolate from Whale Island shore hot vents, strain $\mathrm{W}-12$, is distinguished primarily by its morphological features. Its cells are rather small in size and possess characteristic protrusions. The most interesting protrusions are prostheca-like. Such structures are quite common among mesophilic bacteria (22) and their purpose is, apparently, to increase the cell surface area, which is important for the nutrition of oligotrophs. In extremely thermophilic archaea, the role of prostheca-like structures may be similar to that in eubacteria: namely giving the cell a larger surface area. The new isolates from New Zealand shallow-water hot 


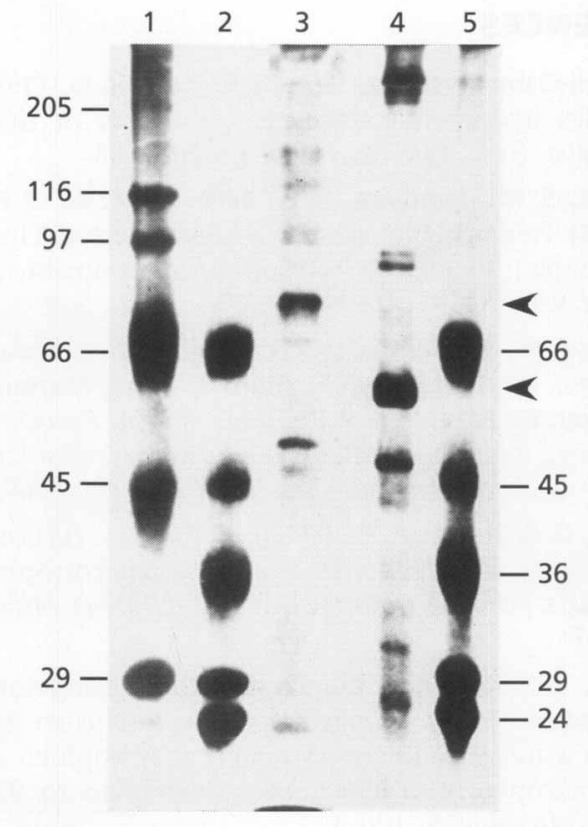

Fig. 4. SDS-PAGE of $W-12$ (lane 3) and P-4 (lane 4) cell-envelope proteins. High- $M_{\mathrm{r}}$ standards, lane 1 ; low- $M_{\mathrm{r}}$ standards, lanes 2 , 5. Arrows indicate regularly structured S-layer proteins (RS proteins).

vents are typical of Thermococcus species in their nutritional features. In the presence of elemental sulfur they grow preferentially on peptides, but do not oxidize them totally to $\mathrm{CO}_{2}$ and $\mathrm{H}_{2} \mathrm{~S}$, producing volatile fatty acids, which is typical for the fermentation of amino acids. The new strains $\mathrm{W}-12$ and P-4 did not show any growth in the absence of elemental sulfur. However, the production of volatile fatty acids during growth indicates that fermentation does occur and is dependent on the availability of elemental sulfur as an external electron acceptor. It follows that, in their physiology as well as in many other characteristic features, the new isolates are similar to representatives of the genera Thermococcus, Staphylothermus and Pyrococcus. The ability to form a network of fimbriae is similar to that of Pyrodictium (23) but, besides a lower temperature optimum for growth, both isolates differ from representatives of this genus as well as from Pyrococcus (4), Staphylothermus (5) and Hyperthermus (28) by having a significantly higher $\mathrm{G}+\mathrm{C}$ content.

On the basis of the 16S rDNA partial sequence comparison and the high similarity values to Thermococcus species, it is clear that the new isolates are members of the genus Thermococcus. The physiological features of the new isolates are also similar to those of members of the genus Thermococcus, and they are therefore assigned to this genus. The 16S rDNA sequence data are useful for assigning the new isolates at the genus level but the similarities are too high to allow differentiation at the species level. Those species of Thermococcus showing greater than $99 \%$ 16S rDNA sequence similarity to the new isolates were compared by DNA-DNA hybridization, the results of which clearly show the lack of relationship at the species level between strains W-12, P-4 and these Thermococcus species (Table 1). Strain W-12 differs from all Thermococcus species in its ability to form prostheca-like structures, from $T$. celer and $T$. fumicolans by the obligate requirement for sulfur, from 'Thermococcus litoralis' and Thermococcus chitinophagus by the significant difference in $\mathrm{G}+\mathrm{C}$ content of the DNA and the requirement for sulfur, and from $T$. stetteri by the cell envelope structure and growth substrates. The differences in growth substrates also differentiate strain W-12 from $T$. profundus, and the strain can be differentiated from T. chitinophagus and $T$. peptonophilus on the basis of its cell envelope structure, growth substrates and sulfur requirement. The high $\mathrm{pH}$ range for growth and low $\mathrm{G}+\mathrm{C}$ content of the DNA differentiates 'Thermococcus alcaliphilus' from the two new isolates. The same characteristics described for strain W-12 above can be used to differentiate strain P-4 from the other Thermococcus species, although its cell envelope is similar to those of $T$. chitinophagus, $T$. peptonophilus and $T$. stetteri. Strains W-12 and P-4 differ in their cell envelope structure and in the formation of prosthecate structures by strain $\mathrm{W}-12$. The results of DNA-DNA reassociation experiments along with the characteristics described above clarify the species status of both of the new isolates. Two new species of the genus

Table 1. Percentage DNA-DNA hybridization of the new isolates with ${ }^{3} \mathrm{H}$-radiolabelled DNA from type strains of some species of the genus Thermococcus

\begin{tabular}{|c|c|c|c|c|c|c|}
\hline Strain & T. celer & T. stetteri & $T$. peptonophilus & $T$. profundus & T. chitinophagus & Strain W-12 \\
\hline T. celer & 100 & - & 4 & 2 & 3 & - \\
\hline$T$. stetteri & 5 & 100 & - & - & - & - \\
\hline T. peptonophilus & 5 & - & 100 & 12 & 3 & - \\
\hline T. profundus & 4 & - & 11 & 100 & 4 & - \\
\hline T. chitinophagus & 3 & - & 3 & 1 & 100 & - \\
\hline Strain W-12 & 5 & 10 & 13 & 10 & 2 & 100 \\
\hline Strain P-4 & 2 & 10 & 8 & 10 & 2 & 54 \\
\hline
\end{tabular}


Thermococcus are proposed: Thermococcus gorgonarius, with the type strain W-2, and Thermococcus pacificus, with the type strain P-4.

\section{Description of Thermococcus gorgonarius sp. nov.}

Thermococcus gorgonarius (gor.go.na'ri.us. L. masc. adj. gorgonarius pertaining to Gorgon, a Greek mythological creature with snakes for hair).

Cells are irregular cocci, $0 \cdot 3-1 \cdot 2 \mu \mathrm{m}$ in diameter, motile with polar flagella. The cell envelope consists of one layer of subunits. The major protein of the cell wall has an $M_{\mathrm{r}}$ of 75000 . Protrusions of different kinds: prostheca-like, chains of bubbles, fimbriae network. Obligate anaerobe. Archaeon. Grows at temperatures $68-95^{\circ} \mathrm{C}$, optimally at $80-88^{\circ} \mathrm{C}$, and at $\mathrm{pH} 5 \cdot 8-8 \cdot 5$, optimally at $\mathrm{pH} 6 \cdot 5-7 \cdot 2$. Grows on peptides; produces weak growth on pyruvate. Does not utilize glucose, maltose, starch, Casamino acids, volatile fatty acids, lactate, alcohols, or molecular hydrogen. In closed vessels growth is dependent on the presence of elemental sulfur which is reduced to $\mathrm{H}_{2} \mathrm{~S}$. Growth products on peptone are $\mathrm{CO}_{2}, \mathrm{H}_{2} \mathrm{~S}$, acetate, propionate, isobutyrate and isovalerate. $\mathrm{G}+\mathrm{C}$ content of DNA is $50.6 \mathrm{~mol} \%$. Source of isolate: sand from the shore of Whale Island, New Zealand. The type strain is strain W-12 (= DSM $\left.10395^{\mathrm{T}}\right)$.

\section{Description of Thermococcus pacificus sp. nov.}

Thermococcus pacificus (pa.ci'fi.cus L. masc. adj. for Pacific Ocean, from the south-west part of which the new organism was isolated).

Cells are irregular cocci, $0 \cdot 7-1 \cdot 0 \mu \mathrm{m}$ in diameter, motile with a bundle of flagella. The cell envelope consists of one layer of subunits. The major protein of the cell wall has an $M_{\mathrm{r}}$ of 56000 . Obligate anaerobe. Archaeon. Grows at temperatures between 70 and $95^{\circ} \mathrm{C}$, optimally at $80-88^{\circ} \mathrm{C}$, and at $\mathrm{pH} 6.0-8.0$ with an optimum at pH 6.5. Grows on peptides and starch. Does not utilize glucose, maltose, Casamino acids, volatile fatty acids, pyruvate, lactate or molecular hydrogen. In closed vessels, growth is dependent on the presence of elemental sulfur which is reduced to $\mathrm{H}_{2} \mathrm{~S}$. Growth products on peptone are $\mathrm{CO}_{2}, \mathrm{H}_{2} \mathrm{~S}$, acetate, propionate, isobutyrate, and isovalerate. $\mathrm{G}+\mathrm{C}$ content of DNA is $53.3 \mathrm{~mol} \%$. Source of isolate: bottom deposits of the Bay of Plenty, New Zealand. The type strain is strain P-4 (= DSM 10394 ${ }^{\mathrm{T}}$ ).

\section{ACKNOWLEDGEMENTS}

The authors are grateful to V. G. Tarasov, Institute of Marine Biology, Far East Scientific Center, Russian Academy of Sciences, for his excellent organization of the cruise in the South Pacific, his help with sampling and his constant interest in the work, and to G. A. Zavarzin, Institute of Microbiology, Russian Academy of Science, for his valuable comments.

\section{REFERENCES}

1. Bonch-Osmolovskaya, E. A. \& Stetter, K. O. (1991). Interspecies hydrogen transfer in cocultures of thermophilic archaea. Syst Appl Microbiol 14, 205-208.

2. Barns, S. M., Fundyga, R. E., Jeffries, M. W. \& Pace, N. R. (1994). Remarkable archaeal diversity detected in a Yellowstone National Park hot spring environment. Proc Natl Acad Sci USA 91, 1609-1613.

3. Erauso, G., Reysenbach, A. L., Godfroy, A., Meunier, J. R., Crump, B., Partensky, F., Baross, J. A., Marteinsson, V., Barbier, G., Pace, N. R. \& Prieur, D. (1993). Pyrococcus abyssi sp. nov., a new hyperthermophilic archaeon isolated from a deep-sea hydrothermal vent. Arch Microbiol 160, 338-349.

4. Fiala, G. \& Stetter, K. O. (1986). Pyrococcus furiosus sp. nov. represents a novel genus of marine heterotrophic archaebacteria growing optimally at $100^{\circ} \mathrm{C}$. Arch Microbiol 145, 56-61.

5. Fiala, G., Stetter, K. O., Jannasch, H., Langworthy, T. \& Madon, J. (1986). Staphylothermus marinus sp. nov. represents a novel genus of extremely thermophilic submarine heterotrophic archaebacteria growing up to $98^{\circ} \mathrm{C}$. Syst Appl Microbiol 8, 106-113.

6. Gillespie, S. \& Gillespie, D. (1971). Ribonucleic aciddeoxyribonucleic acid hybridization in aqueous solutions and in solutions containing formamide. Biochem $J \mathbf{1 2 5}$, 481-487.

7. Godfroy, A., Meunier, J.-R., Guezennec, J., Lesongeur, F., Raguenes, G., Rimbault, A. \& Barbier, G. (1997). Thermococcus fumicolans sp. nov., a new hyperthermophilic archaeon isolated from a deep-sea hydrothermal vent in the north Fiji basin. Int J Syst Bacteriol 46, 1113-1119.

8. Gongadze, G. M., Kostyukova, A. Yu., Miroshnichenko, M. L. \& Bonch-Osmolovskaya, E. A. (1997). Regular proteinaceous layers of Thermococcus stetteri cell envelope. Curr Microbiol 27, 5-9.

9. Gonzalez, J. M., Kato, C. \& Horikoshi, K. (1995). Thermococcus peptonophilus sp. nov., a fast growing, extremely thermophilic archaebacterium isolated from deep-sea hydrothermal vents. Arch Microbiol 164, 159-164.

10. Huber, R., Stohr, J., Honenhaus, S., Rachel, R., Burggraf, S., Jannasch, H.W. \& Stetter, K. O. (1995). Thermococcus chitinophagus sp. nov., a novel, chitin-degrading, hyperthermophilic archaeum from a deep-sea hydrothermal environment. Arch Microbiol 164, 255-264.

11. Keller, M., Braun, F.-J., Dirmeieir, R., Hafenbradl, D., Burggraf, S., Rachel, R. \& Stetter, K. O. (1995). Thermococcus alcaliphilus sp. nov, a new hyperthermophilic archaeum growing on polysulfide at alkaline $\mathrm{pH}$. Arch Microbiol 164, 390-395.

12. Kobayashi, T., Kwak, Y. S., Akiba, T., Kudo, T. \& Horikoshi, K. (1994). Thermococcus profundus sp. nov. a new hyperthermophilic archaeon isolated from a deep-sea hydrothermal vent. Syst Appl Microbiol 17, 232-236.

13. Maidak, B. L., Larsen, N., McCaughey, M. J., Overbeek, R., Olsen, G. J., Fogel, K., Blandy, J. \& Woese, C. R. (1994). The Ribosomal Database Project. Nucleic Acids Res 22, 34853487.

14. Maniatis, T., Fritsch, E. F. \& Sambrook, J. (1982). Molecular Cloning: a Laboratory Manual. Cold Spring Harbor, NY: Cold Spring Harbor Laboratory.

15. Marmur, J. (1961). A procedure for the isolation of DNA from microorganisms. $J$ Mol Biol 3, 208-218. 
16. Marteinsson, V. T., Watrin, L., Prieur, D., Caprais, J. C., Raguenes, G. \& Erauso, G. (1995). Phenotypic characterization, DNA similarities, and protein profiles of twenty sulfur-metabolizing hyperthermophilic anaerobic Archaea isolated from hydrothermal vents in the southern Pacific Ocean. Int J Syst Bacteriol 46, 1113-1119.

17. Miroshnichenko, M. L., Bonch-Osmolovskaya, E. A., Neuner, A., Kostrikina, N. A. \& Alekseev, V. A. (1989). Thermococcus stetteri sp. nov., a new extremely thermophilic marine sulfur-metabolizing archaebacterium. Syst Appl Microbiol 12, 257-262.

18. Neuner, A., Jannasch, H. W., Belkin, S. \& Stetter, K. O. (1990). Thermococcus litoralis sp. nov.: a new species of extremely thermophilic marine archaebacteria. Arch Microbiol 153, 205-207.

19. Owen, R. J. \& Lapage, S. P. (1976). The thermal denaturation of partly purified bacterial deoxyribonucleic acid and its taxonomic applications. J Appl Bacteriol 41, 335-340.

20. Pley, U., Schipka, J., Gambacorta, A., Jannasch, H. W., Fricke, H., Rachel, R. \& Stetter, K. O. (1991). Pyrodictium abyssi sp. nov. represents a novel heterotrophic marine archaeal hyperthermophile growing at $110^{\circ} \mathrm{C}$. Syst Appl Microbiol 14, 245-253.

21. Rainey, F. A., Ward-Rainey, N., Kroppenstedt, R. M. \& Stackebrandt, E. (1996). The genus Nocardiopsis represents a phylogenetically coherent taxon and a distinct actinomycete lineage: proposal of Nocardiopsaceae fam. nov. Int J Syst Bacteriol 46, 1088-1092.

22. Staley, J. T. \& Fuerst, J. A. (1989). Budding and/or ap- pendaged bacteria. In Bergey's Manual of Systematic Bacteriology, vol. III, pp. 1890-1993. Edited by J. T. Staley, M. P. Bryant, N. Pfennig \& J. Holt. Baltimore: Williams \& Wilkins.

23. Stetter, K. O., Konig, H. \& Stackebrandt, E. (1983). Pyrodictium gen. nov., a new genus of submarine disk-shaped sulfur-reducing archaebacteria growing optimally at $105^{\circ} \mathrm{C}$. Syst Appl Microbiol 4, 535-551.

24. Truper, H. G. \& Schlegel, H. G. (1964). Sulfur metabolism in Thiorhodaceae. I. Quantitative measurements on growing cells of Chromatium okenii. J Microbiol Serol 30, 225-228.

25. Stetter, K. O., Fiala, G., Huber, G., Huber, R. \& Segerer, A. (1990). Hyperthermophilic microorganisms. FEMS Microbiol Rev 75, 117-124.

26. Widdel, F. \& Pfennig, N. (1992). The genus Desulfuromonas and other gram-negative sulfur-reducing eubacteria. In The Prokaryotes, 2nd edn., vol. 1, pp. 3379-3389. Edited by A. Balows, H. G. Truper, M. Dworkin, W. Harder \& K.-H. Schleifer. New York: Springer Verlag.

27. Zillig, W., Holz, I., Janekovic, D., Schafer, W. \& Reiter, W. D. (1983). The archaebacterium Thermococcus celer represents a novel genus within the thermophilic branch of archaebacteria. Syst Appl Microbiol 4, 88-94.

28. Zillig, W., Holz, I., Janekovic, D., Klenk, H.-P., Imsel, E., Trent, J., Wunderl, I., Forjaz, V. H., Couyinho, R. \& Ferreira, T. (1991). Hyperthermus butilicus, a hyperthermophilic sulfur-reducing archaebacterium that ferments peptides. J Bacteriol 172, 3959-3965. 